\title{
Solving the Problematic Relationship between Irregular Marketing Behaviours and the Principles of Social Responsibility:
}

\section{An exploratory study in some car showrooms in Basra}

\author{
Hani Fadhil Jumaah Al-Shawi \\ Place of work: Quality Manager at Shatt Al-Arab University College, Basra, Iraq \\ E-mail: dr.hanishawi@gmail.com
}

Received: August 1, 2021

doi:10.11114/bms.v7i3.5331
Accepted: August 17, $2021 \quad$ Online Published: August 19, 2021

URL: https://doi.org/10.11114/bms.v7i3.5331

\begin{abstract}
Reckless marketing has recently become a dirty tool played by modern pirates with a network of gangs, as they tried hard to mix facts as poker cards are on the table, and its danger to social responsibility values has become very worrying in Iraq. Planning, tactics, probabilities and forecasting, and the Iraqi economy has become based on the unknown. Where, unfortunately, the mafia played in its squares, empty polemics from here and there, deceptions and tricks, until they entered the core of factories, and the inputs turned into numbers, and the operations turned into illusions, and the outputs were mere rubble, and the costs were huge, and the returns were despicable Then we continue.. Commercial projects are programmed viruses that strike any system, confuse all standards, destroy all walls of knowledge, and throw seeds of ignorance into the industrial environment instead of quality. We live in an era in which competition revolves around supply, demand, production, productivity, efficiency, effectiveness, knowledge and programming.

But where are we in all of this? The companies of the world are looking for quality while we are digging for scrap? What led us to a culture of mediocre performance instead of outstanding performance? Is it an attempt to abort all academic efforts that theorize and strain themselves in solving puzzles and dilemmas to reach constructive proposals to heal the greatness, satisfy the great Creator, and strengthen the pillars and components of the desired Iraqi economy in light of volatile growth sources.

This study came to reveal the current ambiguous situation in Iraq regarding the performance of deceptive companies that engage in spurious and irregular marketing activity and compare them with honest companies with real marketing and reward the second with its right and rights, and expose the first with all its sighs and stray breath

Where the study was divided into three aspects, the first aspect focused on highlighting the methodology that followed the steps of the study and established the pillars and modalities of the research, while the second aspect focused on a theoretical account of the research variables and a review of the practical side, and we concluded with conclusions and recommendations.
\end{abstract}

Keywords: false marketing, network of gangs, unfair competition tool, inefficient industry environment, social responsibility values, problematic marketing relationship

\section{Introduction}

The experience that many governments of the world have adopted in extending their ownership over large institutions and medium industries to be the main source of economic growth has not achieved its goals for many reasons.

The most important of them is that it depends on economies of scale "large production", and this in turn requires the existence of consumer markets with constant demand in the long run, and this is what cannot be provided in the structure of the new business world

Which is characterized by intense competition, short product life cycle, and extreme diversity in customer tastes

where you live Business organizations today are a new economic stage that requires them to confront open market policies within the so-called stage of the global economy, where international economic relations are intertwined from 
production, processing, marketing and competition within a framework that transcends the regional and local borders of countries to a world without borders, and this resulted in the emergence of small and medium-sized business organizations As it has become the main engine and source of work and production in the developed economies, and now it deals at high levels and returns millions of dollars to the economy of its countries. Therefore, the developed countries have paid great attention to it and directed to prepare special programs for its development and established many organizational policies and administrative and marketing strategies that support its survival and continuity. Within the context of this trend, what is known as resonant marketing and regulated feudalism, which are considered as tools that support the survival, continuity and sustainability of small and medium-sized business projects according to accurate scientific foundations, and provide an efficient and appropriate industrial environment for providing services and diagnosing problems without violating the values, ethics and behaviors of honest marketing free from the phenomena and behaviors of deception. Shadowing as discussed in the current research, and therefore in this research, all practices of companies (car showrooms in Basra) with fictitious, fraudulent or irregular performance were studied and in depth covered their fragile behavior in order to identify their concept, characteristics and opportunities to benefit from their adaptation to serve the economic development process in Iraq and qualify them to become real.

\section{Research Methodology}

The current research methodology consists of seven paragraphs, as follows:-

\subsection{The Research Problem}

The problem of the study is summarized by the legitimate concern that the researcher is trying to disclose its rationale about the danger of the next stage that awaits the Iraqi economy as a result of the heavy burdens left by the cumulative effects of not responding to the warnings that escalate from the local university parties with the shaking and collapse of granting licenses and judicial permissions and the hidden legal coverage for some individuals controlling the Lending and financing of medium and small companies, and the unfair conditions on how to pay them, an attempt to impose feudal behavior, but with more polite labels in front of public opinion and society, as a legitimate means to prevent them, or withhold information about legal accountability, and try to humiliate the public administration and government systems, and policies or intentions of work are hidden in it to weaken and acquiesce in the private and public sector.

And try to answer the following questions:-

a. Can management improvement processes be an effective way to stop these behaviors?

b. Can reforming the corrupt business activities environment turn it into a regulatory business environment that works in the field of financial and judicial regulations to improve the enforcement and conclusion of contracts?

c. Will the pace of reform referred to above contribute to reforming the troubled and irregular marketing activity and reducing its growth?

\subsection{The Importance of Research}

This study attempts to liberate industry and local marketing from the shackles of abusers and expose the looting operations that eat away at the body of the values of social responsibility and the pillars of the Iraqi economy.

Second: Objectives of the study:

a. Giving the private sector an adequate opportunity to play its real role in improving the quality of the market environment, strengthening our local economy and achieving economic development.

b. A statement of the most important obstacles facing the private and public sector and ways to get rid of them.

c. Introducing the private sector to its importance in industry and competition, and not to play the role of an indifferent spectator of the results of false exports and imports from exporting countries and the Iraqi consumer.

d. The whims and inclinations of the companies dominating the Iraqi industry have no possibility between expansion and Iraqi ambition.

e. Spreading a culture of transparency and integrity in the private sector to be trusted by international lenders.

f. Attempting to awaken the conscience of officials in the Iraqi state and remind them that it is time for the government side to believe in the importance of the private sector in building the country's economy.

g. The research attempts to clarify the role of the private sector in the necessity of building high-quality, broad-based economic projects of good societal value that support the reality of human development and its sustainability in a way that encourages international monetary authorities to cooperate with it.

h. Enhancing the private sector's awareness of paying attention to public relations and the media in a way that enables it to build bridges of connection with major international companies and international lending authorities. 


\subsection{The Default Search Form}

The hypothesis of the research was built based on the vision of (Reid \& Roowmaat:2003) through the impact of the reform process and its impact on society and the economy as shown in Figure (1) below

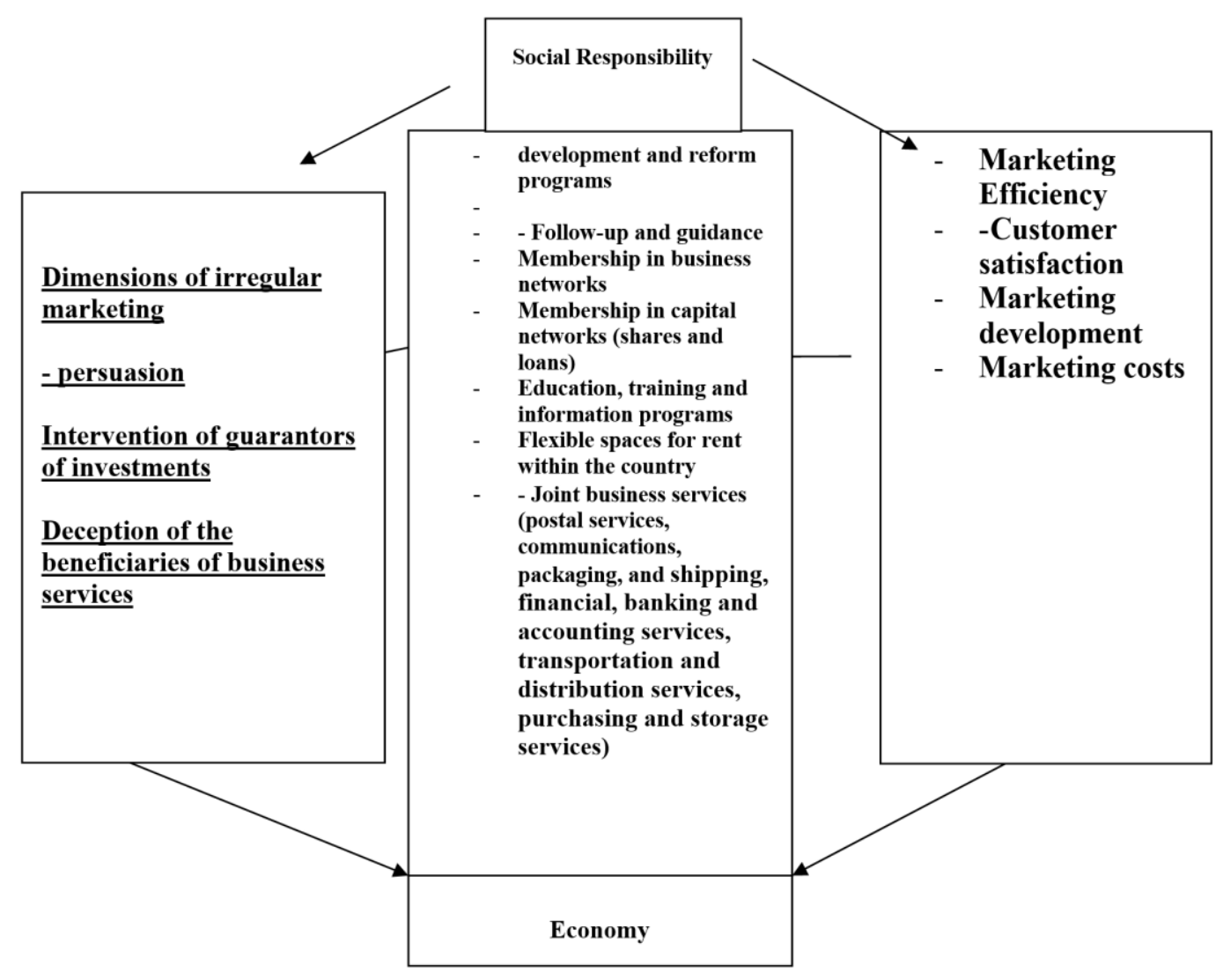

Figure 1. Hypothesis Research Scheme

Source: Reid \& Roowmaat:2003)" Business incubation: review of current situation and guidelines for government intervention in Estonia: : https://www.researchgate.net/publication/312612502: DOI: 10.13140/RG.2.2.10373.76009.

\subsection{Prepared by the Researcher Research Community and Sample}

Research community: All employees and dealers in car showrooms in Basra

The research sample: a mixture of the opinions of customers and employees of Basra car dealerships, and (66) of them were randomly selected

Fifth: Research hypotheses

Since there is a possibility to reform the absurd marketing activity by raising awareness of the concepts and dangers of irregular marketing and the values of social responsibility in Basra showrooms for selling damaged and remanufactured cars and trying to deceive customers in devious ways as they are unaware of the dangers of using them. Based on that, the following hypotheses emerged:

a- The first main hypothesis:-

There is a significant correlation between irregular marketing and marketing efficiency at the overall level

The first sub-hypothesis:

There is a significant correlation between the dimension of deception and marketing efficiency at the overall level

b- The second sub-hypothesis:

There is a significant correlation between the intervention dimension and marketing efficiency at the overall level, the 
third sub-hypothesis:

There is a significant correlation between the dimension of persuasion and marketing efficiency at the overall level

\subsection{Statistical Research Tools}

Percentages, arithmetic means, standard deviation, correlation, regression, and using the SPSS statistical package.

\subsection{Measurement Tool or Search Scale}

The researcher established a scale for the current research variables based on the scientific and knowledge sources that went through the research variables, which are the irregular marketing variables and its dimensions and the social responsibility variables for the marketing efficiency of companies within the framework of development and economic reform programs. The table (1) below shows the dimensions and variables of the research.

Table 1. Measurement dimensions

\begin{tabular}{|c|c|}
\hline main variable & Sub-variable \\
\hline \multirow[t]{3}{*}{ Irregular Marketing Parties } & persuasion \\
\hline & Intervention of the guarantors \\
\hline & deceive the beneficiaries \\
\hline \multirow[t]{3}{*}{ development and reform programs } & Follow up and advice \\
\hline & Membership in capital networks \\
\hline & business services \\
\hline \multirow[t]{4}{*}{ Dimensions of marketing efficiency } & $\begin{array}{l}\text { Reducing social, environmental and economic damages } \\
\text { through the following sub-dimensions: }\end{array}$ \\
\hline & Customer satisfaction \\
\hline & Marketing development \\
\hline & marketing costs \\
\hline
\end{tabular}

Source: Prepared by the researcher

\section{The Theoretical Approach to Research}

This aspect consists of three sections, where the first section is devoted to a theoretical presentation of independent and dependent research variables, the second to previous studies, and the third to practical presentation.

\subsection{Irregular Marketing and Marketing Efficiency}

\subsubsection{Irregular Marketing}

The concept of fake or irregular marketing, gang marketing or gorilla marketing is based on the use of low-cost and non-traditional means (such as graffiti, posters, etc.) in a local setting (in general) to attract attention to an idea, product or service [Boston, 2014][Bomb, 2017] \& [Scare, 2016].

The term guerrilla marketing today has evolved to include other things such as promotion through a network of individuals, groups, or organizations that work to spread knowledge of a particular product or idea through the use of strategies such as rallying, viral marketing, or online advertising. its types

\section{External Marketing}

Outdoor advertising is an advertisement presented to elements of the environment, including nearly every available physical surface.[ Gambetti:2015] It is a combination of intelligence, flexibility and efficient use of the atmosphere around us. This type of advertisement can be found anywhere and everywhere from hand dryers in public restrooms and petrol pumps to bus seat belts and golf ball cans.[ Solomon\& Marshall. And Stuart: 2008]

\section{Irregular marketing.}

Irregular marketing is the intentional act of entering, operating in, or exiting a market in a malicious, covert or imperceptible manner, or an attempt to do so.[ Chadwick And Burton:2010] 


\section{Viral Marketing}

Viral marketing describes any strategy that encourages individuals to pass on a marketing message to others, and this creates the potential for exponential growth in message exposure and impact. Like viruses, such strategies benefit from the rapid spread of the message to thousands and millions of people. Viral marketing outside the Internet has been referred to by several names, such as: word of mouth, utilizing media, network marketing, but on the Internet, it is called viral marketing. [Baker. \& Hart:2008]

Likewise, this type of marketing uses high-profile media to encourage the audience to discuss the brand or product. It works best when consumer responses are genuine to a product or service, that is, without the company paying them for it. [Solomon\& Marshall. And Stuart: 2008]

\section{Popular Marketing}

Popular campaigns aim to win customers individually. A successful popular campaign is not about spreading the marketing message in the hope that potential consumers will be interested in it, but rather highlight the personal relationship between the consumer and the brand and make this relationship permanent [Heinemann:2012].

\section{False popular propaganda}

False populist advertising is among the most controversial gangster marketing strategies, and poses a significant risk factor for a company marketing a product or service in this way. Case in point: artificial turf, often used on soccer fields or tennis courts - also known as fake turf. False publicity involves creating artificial hype about a particular product or company through a written review or discussion on blogs or online forums by an individual who is paid to convey a favorable view. This can have a negative and detrimental effect on the company, if the consumer suspects that the review or opinion is not true, and this harms the company's reputation, or even worse, leads to the company being sued. [Jacobs:2012]

\section{Street Marketing}

Street marketing uses unconventional means to advertise or promote products and brands in public places. The main objective is to encourage consumers to remember the brand or product marketed for it. Since street marketing is part of gang marketing, it includes all marketing activities that are carried out in the streets and public areas, such as: parks, streets, events, etc. It also includes outdoor advertising, such as shopping carts (US shopping carts), public toilets, public transportation, porthole covers, footpaths, trash containers, and others. [Berman:2007]

Street marketing is not limited to static advertising. Organizations commonly use brand ambassadors to distribute product samples or discount vouchers, and to answer product inquiries with an emphasis on branding. Brand ambassadors may accompany a booth with product samples or illustrative materials. Physical interaction with consumers has more influence than traditional passive advertising. [Stefania, Luca, Sherry, \& John 2010]

Street marketing is understood as enhancing the imagination and not just filling spaces: the imagination of street culture and street art. [Neville:2009] Millennials, which are broadly made up of urban youth (15-30 years old), are often seen as the most vulnerable target of these campaigns due to their association with street culture. [Saucet \& Cova:2014]

According to [Marcel Saucet and Bernard Cova, 2014], street marketing can be used as a general term that includes six main types of activities:

- Distribution of brochures or products

This is the most traditional activity and the most common form of street marketing used by brands.

- Animation of the product

This activity consists of allocating a high-traffic space using brand imagery. The idea is to create a small world in order to promote a new product or service.

- Human Animation

The goal of these actions is to create a space for communicating the brand's message through human activity.

- Road Shows

It is a form of animated display based on transportation: taxis, bicycles, and other means.

- outdoor activities

These activities include elements from the street.

- Public event activities

These activities take the form of surprise gatherings, the idea of which is to promote a product, service or brand value 
by organizing a public event.

typical procedures.

Companies initially identify suitable public places for developing marketing campaigns, such as: beaches, cultural events, places near schools, sporting events, and children's entertainment areas. [Saucet \& Cova:2014] Next, these companies have to develop a plan to approach the different media and target market. In order to attract attention, street marketing events are not only restricted to unusual activities but technology is used as a part of it. The purpose is to increase the value of the campaigns and attract the attention of potential consumers [Lena:2014].

Besides, companies' plans take into account that gang or street marketing involves global communication and interaction and not just with customers or the media [Ja Conrad Levinson: 1984].

It has also been developed to identify opportunities and gather sufficient information about products, markets and competitors. For example, for a business, it is more important to retain customers, rather than choosing competitors' offerings. Companies apply innovative strategies to maintain their market position, in addition to using advertising through other means, such as radio and television, when using street marketing [Jay :2000].

There are various examples of strategies used in gang marketing; One of them is making offers to increase sales. In many cases, companies don't just offer their products or services for recognition, but also to offer other things for free. Another example: is to offer fundraising offers, the goal of this strategy is to help other organizations such as schools, by providing them with financial support. Most companies apply this method not only to increase their sales, but also to improve their reputation and image in the community. Finally, there is a strategy called (group selling) which consists of groups of people, mostly young people, roaming homes in different neighborhoods, with the aim of helping companies promote and sell their products or services [Auletta, 2009] \&[Jay, 2000].

When applying gang marketing or street marketing, organizations also consider focusing on the psychological approach. For many companies, that means whether or not they are successful. Street marketing focuses on some psychological aspects of knowing customers' behavior and preferences. For example, certain psychological regions study how people's brains are divided: (45\%) of people are left-brained, (45\%) are right-brained, and (10\%) are balanced. Left-brained people tend to be logical, right-brained people tend to be emotional, and the rest combine the two. Next, the companies decide how they will run their street marketing campaigns according to the product or service the companies offer, as well as the type of customer. Besides, almost all companies base their street marketing campaigns on the repetition of the messages they spread among their customers. This repetition is related to the unconscious part of the mind. He is responsible for making decisions. [ Barry:2002]

3.1.2 Types of marketing in general [Stage \& Sophie :2012]:-

- Social Shopping

- Green Marketing

-E-Marketing

- Social Marketing

- Civilized social marketing

-Marketing Services

- Gang Marketing

- Marketing the case

-Referral Marketing

- Marketing by permission

- Kinetic Marketing

-Timing Marketing

- Internal Marketing

- International Marketing

- Agricultural Marketing

- Comprehensive Marketing

-Network marketing

-Industrial Marketing 
- Viral Marketing

- Relationship marketing

- Marketing databases

-Knowledge Marketing

- Direct Marketing

-Connected Marketing

- Community Marketing

-Socially Responsible Marketing

-Targeted Marketing

- Hierarchical marketing

- Horizontal integration

- Gorilla marketing

\subsubsection{Guerrilla Marketing}

Guerrilla Marketing is an advertising strategy that focuses on low-cost, uncommon marketing tactics to get great results.

The term was first used by Conrad Levinson in (1984) through his book Guerrilla Marketing (which has sold more than (21) million copies to date) and Guerrilla Marketing was inspired by Guerrilla warfare. In which small, unconventional combat strategies are used by armed people within an area or a fierce battle (the origin of this word is Spanish, where the word (Guerrla) means war and the word Guerrilla means small war). These tactics include ambushes, sabotage, raids, and the use of surprise. Just like Guerrilla marketing, Gorilla marketing uses the same tactics in its marketing campaigns. "I would describe the Gorilla spirit as achieving familiar goals like profit and enjoyment through unconventional methods like using physical energy instead of money."'Crescenti \&Brooke :2005]

This alternative style of marketing relies heavily on unusual strategies, activity and imagination. It also depends on surprising the customer and leaving an unforgettable impression on him, in addition to creating a huge media sensation.

This type of creative marketing is suitable for small companies that usually need to reach a wide audience without bankruptcy of their bank account, as it gives these small companies a distinct advantage over large companies. It is also used by large companies as an aid campaign that complements the large campaign on the main marketing channels. And it can sometimes be used by some people as a way to get a job or a job.

3.1.4 Types of creative marketing (Gorilla marketing). [Goldman\& Ric. :2005]

1- Outdoor (Outdoor Guerrilla Marketing)

This type is intended to add something to an existing urban environment, such as placing something removable on a statue or placing temporary artwork on the sidewalks in the streets.

2- Indoor Guerrilla Marketing Unlike the first type, it depends on closed places, as it only occurs in closed places such as train stations, shops, and university campus buildings. Where marketing strategies are implemented in large places and spaces to gain the attention of the largest number of people.

3- Event Ambush Guerrilla Marketing

Marketers in this type try to take advantage of the audience of a specific event such as a concert or a sports game to promote a product or service in a noticeable way, and usually this is done after obtaining

With permission from the leading authorities of the event.

4- Interactive marketing.-- [ Johansson.:2005].

This type includes the three previous types or one of them, but with an emphasis on the audience interacting with what they see in front of them.

3.1.5 Ethics of social responsibility to achieve the principles of market Marketing Efficiency

Principles of Marketing Efficiency [Kaikati, Andrew \& Kaikati:2004].

\subsubsection{The concept of marketing efficiency}

Efficiency is one of the modern topics that organizations in general and the research organization in particular have been interested in, as it is an important element in achieving its goals through what organizations possess from individuals who possess experience, skills and knowledge [stair:2002] 
[stair:2002] considers marketing efficiency as achieving marketing activities to the best of their ability [ Kaikati: 2013].

- From the point of view of [Al-Rawi and Al-Sanad :.2001] that it is an improvement

Marketing outputs through optimal use of inputs

- And ([Abu Fara: 1998] adds that it is to achieve the same marketing outputs with the least possible costs

And he added [stairfgearg, 2005] that they are marketing activities that focus on the needs of targeted customers.

And [kotler:2009] adds that marketing efficiency is nothing but marketing activities that contribute to satisfying the needs and desires of targeted customers[Martin, Kelly. \& Craig N. Smith. :2008].

And [Arnold:2005] indicated that marketing efficiency is nothing but satisfying the needs of the target groups of customers and providing the best for the target customer audience compared to others.

[Marius :2008] considers marketing efficiency as nothing but the customer's acceptance of the services provided by the organization.

And through what the researchers applied, the researchers see that marketing efficiency is nothing but a better exploitation of marketing activities, which ensures the achievement of a satisfactory level of marketing outputs with as few dilemmas as possible. [Jack:2008]

\subsubsection{The Importance of Marketing Efficiency [Robin\& Gensicke :2008]}

Organizations have a lot of resources, and their success and achievement of their goals are not measured by what they have of resources always efficiently. Exploiting those resources optimally ensures their success and achieving their goals. Thus, marketing efficiency becomes a characteristic of honest business to achieve construction and growth[Roy \& Chttopadhyay:2010]\&[Robin\& Gensicke :2008] the importance of marketing efficiency drives the efficient exploitation of material and human resources that will achieve their survival and survival.[ Jack:2008]

As for the point of view [Robin\& Gensicke :2008] looks at the importance of marketing efficiency in organizations through achieving the marketing goals that they seek, and this results from the best use of resources that those organizations do not consume.

And [Roy \& Chttopadhyay:2010] pointed out the importance of marketing efficiency through planning and organizing marketing operations, influencing employees and controlling them, and separating them as follows:-[ Robin\& Gensicke :2008]

1- Marketing operations planning: It depends on forecasting the resource needs, making the necessary preparations, and providing what is appropriate for the organization in reducing costs and in order to achieve a satisfactory level of marketing services, in addition to finding successful solutions to the expected problems when planning and developing alternatives to take the appropriate decision.

Organizing marketing operations: Organizing the activities of employees, determining the interrelationships between them, giving them the necessary powers to perform business and providing them with everything that helps them perform their jobs.

Influencing the workers: - Creating a state of influence in the workers by satisfying their needs and desires, which leads to:

. Achieving employee satisfaction in marketing activities by achieving only the same target

. Achieving customer satisfaction by reducing prices and improving product quality

2. Marketing Operations

By matching marketing operations with the planned goals and objectives to measure the performance of employees and know their efficiency, and thus makes the efficiency of marketing efficiency a role in ensuring the survival and continuity of organizations and an important economic measure to measure market performance

3- Difficulties

4- Effects of measuring marketing efficiency

The researchers did not agree on specific effects of marketing efficiency, so some of them were reviewed according to agreement [Robin\& Gensicke :2008] and [Robin\& Gensicke :2008]

1- Marketing costs:

Reducing marketing costs is one of the important things that organizations seek in return to provide outputs at a satisfactory level in the target markets, and the measure of marketing efficiency according to this indicator is done by 
comparing the total percentage of marketing costs with the total --, production and marketing costs.

And from my point of view [Sakai, Mokoto:2013], they are costs that the economic unit learns to store, advertise, promote, transport and distribute production, and adds [Scott: 2007] It is the difference between the price that the customer pays for his purchase of the commodity and the price of producing the commodity, and it consists of direct and indirect marketing costs. between distribution areas.

And looks [Sakai, 2013], there are a number of factors that affect marketing costs, including:

-Perishability of goods: especially when transporting long distances

-Seasonality of production: especially in agricultural products

-Product homogeneity: the greater the homogeneity of the products, the lower the individual costs.

-Manufacturing: The higher the manufacturing process, the higher the costs

- Item: The customer's knowledge of the product category reduces advertising costs

Price levels: In the event of price stability, the share of the product is equal to the value of the marketing costs

- Quality of customers: If the interacting customers are companies that led to a decrease in costs

Customer satisfaction: Customer satisfaction is one of the important influences of marketing efficiency through the organization's pursuit of customer satisfaction by reducing the prices of products and providing them with high quality [Weilbacher, 2001]

From the point of view [Alexandria Pfleiger Friedberg, 2009] it is the efforts made by the organization to determine the extent of customer satisfaction through the procedures and programs provided by the organization so that it becomes more responsive to the needs and aspirations of customers.

And [Vladimir, Zhechev :2015] referred to satisfaction as judging the quality of products based on what the customer expects and actual performance.

From the point of view: [Karolina \& Sabina, 2005] that the customer's conviction through what the interaction between the organization and its customers provides

And [Sakai, Mokoto. :2013] indicated that customer satisfaction is the extent to which the customer is satisfied with searching for alternatives to the products offered by the organization.

As for [Scott, B.:2007] it refers to the customer's desires as a set of characteristics that organizations can achieve for their customers in a way that is comparable to what competitors offer. And he went [Pettersson \& Markus. :2010] to contentment that it is the judgment issued by the customer through his consumption of the good or service.

And from the point of view [Alexandria Pfleiger Friedberg, 2009] that customers' expectations and satisfaction with a product activate a group of factors that affect the customer's thinking are:

1- WORDWORD: Satisfied customers talk about the product and the good stuff

2- Personal needs: The needs of customers differ from one customer to another, and according to what customers expect from the performance of the products offered by organizations.

3- Previous experience: It is one of the important and most distinguishing factors to raise what the customer expected about him.

Product and service, which is the most distinctive way to order a commodity than not to order it

\subsubsection{Marketing development}

Marketing development appears through the amount and type of information provided by the organization, which helps it to find new marketing opportunities that contribute to satisfying the needs and desires of customers and solving the issues faced by the customer as a result of his use of new goods [Zyman, 2002] marketing development appears through the preparation of strategic plans and the process of implementation is carried out through the information provided by marketing research, especially in the marketing environment through which marketing efficiency is achieved. [Zyman, 2002] looks at the marketing development by studying the variables that occur on the product And trying to provide products that satisfy the needs and desires of customers compared to the products of competing organizations And from the point of view of [Zyman, 2006] that marketing development is through the development of customer needs and respect for competition between competing organizations and the difference in the method of purchase and the multiplicity of products provided

[Alexandria Pfleiger Friedberg, 2009] refers to the marketing development as the stage of defining the product according to the customer's desire and meeting his desires on an ongoing basis. It is a comprehensive study of 
development in a way that meets the requirements of customers.

\subsection{Previous Studies}

3.2.1 Study (Abdulwahab Souissi.) entitled "Management with social responsibility as an entrance to consumer protection: the hidden face of marketing" 2020

The content and focus of this study and the field of its application

It is common knowledge that the institution, through marketing practice, seeks to reach the largest possible segments of the consumer audience, and from it achieve the largest possible market share, and this is within the framework of an environment whose main advantage is creeping competition.

In light of these data, the institution must carry out the necessary marketing research to discover the dark sides of consumer behavior and transform it into the form of goods and services that achieve adequate gratification through the purchasing act. And in the face of the extensions known by the variables of the marketing equation, which went in an attempt to influence consumer behavior to great lengths, many issues of value and moral dimension are being raised, and they often conflict with the nature of man and his environment.

Which led to the search for approaches and methodological alternatives through which we try to re-pose the marketing problem and its limits. This means that the impact of advertising, both positive and negative, is not reflected on the target segment of the advertisement, but rather on the whole community and extends it to other societies. Also, the development of media technology has a steady role in reshaping consumer, behaviors across the globe, which requires strengthening immune systems and protecting against behavioral distortions in the marketing field.

3.2.2 The study of Raad Adnan Raouf, Assistant Professor - College of Administration and Economics, University of Mosul - Republic of Iraq

Unregulated marketing: is it a tool to deceive the customer? Or to promote purchasing behavior?

Article 9, Volume 38, No. 4, 2018, Page 167-184

The content and focus of this study and the field of its application

This study sought to explore the implications of a contemporary marketing strategy represented in Stealth Marketing, as a product of development in the context of the work of contemporary marketing institutions and the urgent need to leave traditional methods in marketing activity that no longer work in achieving its multiple goals, which stands in Its introduction is creating demand by influencing customer behavior, where the irregular marketing strategy is a lifeline for many contemporary companies to get out of the customer's reluctance crisis in the new millennium and not being convinced by what is offered of traditional promotional means that have become boring to him. Therefore, it was no longer able to achieve the desired effect in the mind of the customer, which is reflected in his preferences and purchasing decisions, so it was necessary to search for means that were more effective in the mind of the customer and more able to motivate him towards the offered products.

According to the foregoing, this study attempted to analyze the contents of this strategy and try to find logical explanations for the problem of its adoption that were disputed by two visions.

while the other sees it as a tool to mislead the customer and influence his available options and his purchasing decision. The title of the study reflects its problem in the seriousness of using the irregular marketing strategy to promote purchasing behavior, or in deceiving the customer, according to an analytical vision of the theoretical theses of this strategy, as well as strengthening the results of the analysis through A statement of the effect of this strategy on the purchasing behavior of a random research sample consisting of (200) customers in the Family Mall), the largest shopping center in Erbil Governorate / Kurdistan Region of Iraq. . Ver-19)

Based on the conclusions reached by the researcher, a number of suggestions were made, perhaps the most prominent of which is the need to strengthen the positive aspects of irregular marketing by avoiding the methods of misleading and intimidation in presenting the advertising message through any of its techniques to convince the customer and influence his purchasing decisions and thus the inevitability of leaving Or reduce reliance on traditional methods of persuasion within the promotional activity of local companies.

3.2.3 Study by Ahmed Rashad Mohamed Othman 2019* titled

Hidden perception as innovative marketing and its role in financing Egyptian sports clubs

Scientific Journal of Physical Education and Sports Science. Helwan University Article 20, Volume 85, January Part 1 Serial Number (85)

The content and focus of this study and the field of its application 
The research aims to identify hidden cognition as innovative marketing and its role in financing the Egyptian sports clubs. individuals, and the survey sample amounted to (30) individuals, with a percentage of (22.38\%), and the application was applied in the period from Monday, May 1, 2018 AD until Tuesday, May 16, 2018, and the basic sample amounted to (104) individuals, with a percentage of $77.61 \%$, and was applied in From Wednesday, May 23 to Sunday, July 22, 2018, the researcher concluded: Hidden cognition as innovative marketing is not limited to a specific marketing method. Through it, it is possible to reach larger segments of members by using distinctive hidden marketing methods if compared to the methods of competing clubs, as it represents an important part of the marketing management responsibilities of the sports club, but the sports club does not use hidden logos and signs as innovative marketing during competitive activities, which it loses a lot to promote its activities. Where innovative marketing can contribute to increasing the financing of the sports club, raising the position of the sports club in the community and promoting various sports activities in the sports club.

The performance of the innovative marketing department contributes to marketing the performance of other departments in the sports club, and contributes to achieving higher quality in its activities than the competing clubs. Increase funding for the sports club

\subsubsection{The study of Ali Muhammad Al-Khatib}

The effect of marketing deception in building the mental image of customers in the Jordanian service market (2011) Middle East University College of Business physical environment).

The content and focus of this study and the field of its application

The study aimed to demonstrate the impact of marketing deception in its dimensions (deception in commodity and service products, deception in promotional information, deception in pricing, deception in the market) (the physical environment).

In building the mental image of the customers of companies operating in the Jordanian market and according to the cognitive, behavioral and emotional behavior. The problem of the study lies in the spread of fraud and marketing deception cases in the general trade judges in Jordan, which leads to the danger of spreading a well-established culture of marketing deception.

The study reached a number of results, such as:

The presence of marketing deception in Jordanian trading companies and its negative impact on customers in Jordan, which leads to a reflection on the negative mental image formed on customers. Also, companies in Jordan practiced all kinds of marketing deception at a very high level. The study presented a set of recommendations, the most important of which is the need to activate The supervisory role at all levels, at the official and popular levels, and then working on educating customers in Jordan of the need to get rid of forms of marketing deception by reviewing the teachings of the heavenly religions that forbid all kinds of deception and fraud.

3.2.5 Study Amin Zaidan Khalaf and Randa Saadi, entitled "Hidden Marketing", a theoretical presentation, University of Baghdad, Iraq (Meteorology Journal of Economic and Administrative Studies, Volume 3, Number 3, December 2020, page 1 to 12 )

The content and focus of this study and the field of its application

This study covers the concepts of the field of irregular marketing completely, and the problematic presented aims to reveal the factors that led to its spread and its most important advantages and disadvantages. Various hidden marketing strategies (Ghost marketing) were also listed. The most important findings of the study are

Ghost marketing practices lead to negative responses among customers at the moment of their discovery, and they are often inconsistent with the social concept of marketing.

\subsubsection{Principles of Gang or Gorilla marketing}

Gorilla marketing, as described by Jay Coon Rad Levinson in his famous book Guerrilla Marketing 1982, is an irregular way to carry out promotional activities with a very low budget. covert or covert marketing mystery shopping)

Principles of guerrilla marketing A creative person devises irregular methods of promotion and must use all his professional or personal contacts as well as test the company and its products and search for cheap and free advertising sources and this leads to a step towards increasing the profitability of organizations illegally and Louis Vinson identifies the following principles of marketing gangs

1 Rely on human psychology rather than experience, judgment and guesswork.

2 Invest in imagination and image instead of money. 
3 key stats to measure a business are profitability, not sales.

4 Focus on existing customers, not new customers.

5 We should forget about competition and focus on cooperating with companies instead of confronting them.

6 Using modern technology as a tool to enable marketing.

7 Focus on the new relationships that salesmen build with the public every month.

8 Use of political marketing.

9 A set of marketing methods and techniques must be used in a set of procedures and operations

Although this is possible, gang marketing has become a general trend and a simple ploy of small businesses. General electric, yahoo, city grope, and Sony recon.

Apply the principles and practices of gang marketing.

Gang marketing is a vague word and concept that has recently been used to describe many types of traditional marketing methods such as:

- Viral marketing through social media such as WhatsApp Messenger, Telegram, Instagram, Twitter, Facebook, Tik Tok, YouTube.

- Environmental Marketing Ambient presence.

- Grassroots Marketing.

Alternative marketing alternative

- Verbal marketing buzz.

- Secret or covert marketing series behind the scenes.

The researcher believes that marketing based on the above is that there is a new marketing that has emerged recently called barbaric marketing.

\subsection{Comparison between Traditional Marketing and Gang Marketing}

Levinson cites 12 differences in traditional and gang marketing, which we show in Table (2) below.

Table 2. The most important differences between traditional marketing and irregular marketing, gang marketing

\begin{tabular}{|c|c|c|}
\hline $\mathbf{s}$ & traditional marketing & Gang Marketing \\
\hline 1 & Investing money in the marketing process & $\begin{array}{l}\text { An initial investment that focuses on time, energy and mental } \\
\text { image }\end{array}$ \\
\hline 2 & It offers big budgets & Offers small budgets \\
\hline 3 & Measures doing business through sales & Measured by profit \\
\hline 4 & Depends on experience and judgment & It is based on human psychology and the laws of behavior \\
\hline 5 & $\begin{array}{l}\text { It proposes to increase business production rates and rates and } \\
\text { then diversify through product offerings }\end{array}$ & $\begin{array}{l}\text { On the tricks, tricks and low budget for advertising and } \\
\text { promotion, not diversification of products }\end{array}$ \\
\hline 6 & $\begin{array}{l}\text { Focuses on linear business development by adding new } \\
\text { customers }\end{array}$ & $\begin{array}{l}\text { Focuses on business development in an engineering way by } \\
\text { focusing on transactions with existing customers and tracking } \\
\text { them with key services }\end{array}$ \\
\hline 7 & $\begin{array}{l}\text { It requires searching for opportunities to eliminate } \\
\text { competition }\end{array}$ & $\begin{array}{l}\text { It requires forgetting the issue of competition and searching } \\
\text { for job opportunities and cooperating with other companies in } \\
\text { a mutual effort to achieve profit }\end{array}$ \\
\hline 8 & $\begin{array}{l}\text { Traditional marketing makes advertising on a website } \\
\text { important }\end{array}$ & $\begin{array}{l}\text { Advertising in the web is the key to success in marketing and } \\
\text { advertising must be combined with direct mail to perform the } \\
\text { task better }\end{array}$ \\
\hline 9 & Confirms the profit account every month & $\begin{array}{l}\text { Focuses on how to find out the many relationships you build } \\
\text { each month }\end{array}$ \\
\hline
\end{tabular}




\begin{tabular}{|l|l|l|}
\hline 10 & Not related to technology & Technology is appreciated because it is easy to use and cheap \\
\hline 11 & $\begin{array}{l}\text { Identifies a simple set of traditional promotional strategies } \\
\text { that are believed to be relatively costly }\end{array}$ & $\begin{array}{l}\text { Alif identifies the methods that can be used to increase profits } \\
\text { for free }\end{array}$ \\
\hline 12 & $\begin{array}{l}\text { It scares business owners because it is full of grandeur and } \\
\text { complexity }\end{array}$ & $\begin{array}{l}\text { It undermines the greatness of marketing and shows what } \\
\text { exactly marketing is the factors that control entrepreneurship }\end{array}$ \\
\hline
\end{tabular}

Source: Table prepared by the researcher based on Levinson's citation.

\subsubsection{Gang Marketing Implementation Steps}

Gang marketing is a process and not an event as a revolution launched by Levinson that can win real battles with profit, and they are as follows (wpaid.org 2021):-

1. Research the market for product, service, media, competitors, customers and technology and integrate with potential marketing partners

2. Write a list of the benefits offered by your company and hear the opinions of customers to complete this list

3. Choose the marketing tools for your attacks and select the start date of the attack

4. Design a marketing plan that can implement the specific goals of your company. The plan must be creative, as it can be a message to the target markets.

5. Create a gang marketing calendar, make decisions and avoid accidents

6. Apply corrections and adjustments to marketing partners

7. Run the attack at an emotionally and financially correct pace

8. Immediately protect and support the attack and maintain the offensive position to achieve a guaranteed victory

9. Evaluate the attack by measuring its effectiveness and efficiency in the market

10. Improve the attack in all areas, top the color scale and budget, and make continuous improvements.

3.3.2 Conditions for applying the gang marketing streak

Levinson believes that a gang marketing plan can be designed in seven conditions

1. Describe the purpose of the strategy

2. How to achieve this purpose

3. Description of the target market

4. List the marketing activity that will be used

5. Describe the profitable market corners

6. Work identification

7. Budget statement as a percentage not the beauty of the forecast data.

3.3.3 The secrets of the creative strategy in irregular marketing

Levinson points out the secrets of the creative strategy in irregular marketing, as follows:

1. Adhere to the marketing plan

2. Invest in that plan

3. Reconsider the stability of the program

4. Build trust with potential customers

5. Be patient in order to maintain commitment

6. Think of a range of alternatives to marketing

7. Ensure that profits and benefits follow sales

8. Starting a Business That Fits Clients

9. Introduce the element of surprise and surprise in marketing

10. Use measurement to judge the effectiveness of products 
11. Creating cooperation between businessmen and customers

12. Use technology and its ammunition, software and hardware well

\subsection{The Third Topic: - Scientific Presentation of the Research Variables}

\subsubsection{Statistical Description of the Research Variables}

This paragraph aims to know the level of the research dimensions (irregular marketing and marketing efficiency) through the use of the arithmetic mean, standard deviation, percentage, and each dimension obtains an arithmetic mean less than 3 hypothetical mean or a percentage less than $60 \%$ is considered rejected.

Table 3. Frequency distributions, arithmetic means, and standard deviations of the dimensions of irregular marketing

\begin{tabular}{|c|c|c|c|c|c|c|c|c|c|c|c|c|c|}
\hline \multirow{2}{*}{$\begin{array}{c}\text { Contrast } \\
\text { source } \\
\text { dimensions }\end{array}$} & \multirow{2}{*}{$\begin{array}{c}\text { code } \\
\text { influencer }\end{array}$} & \multicolumn{2}{|c|}{$\begin{array}{c}\text { Strongly } \\
\text { agree }\end{array}$} & \multicolumn{2}{|c|}{ I agree } & \multicolumn{2}{|c|}{ Neutral } & \multicolumn{2}{|c|}{ Disagree } & \multicolumn{2}{|c|}{$\begin{array}{l}\text { Strongly } \\
\text { disagree }\end{array}$} & \multirow{3}{*}{$\begin{array}{c}\begin{array}{c}\text { Arithmetic } \\
\text { mean }\end{array} \\
3.6621\end{array}$} & \multirow{3}{*}{$\begin{array}{r}\begin{array}{r}\text { Standard } \\
\text { deviation }\end{array} \\
0.6145\end{array}$} \\
\hline & & f & $\%$ & f & $\%$ & f & $\%$ & f & $\%$ & f & $\%$ & & \\
\hline \multirow[t]{5}{*}{ persuasion } & $\mathbf{X} 1$ & 14 & 20.4 & 45 & 68.7 & 3 & 5.8 & 4 & 5.9 & - & - & & \\
\hline & $\mathbf{X} 2$ & 13 & 18.2 & 36 & 51.8 & 13 & 18.2 & 2 & 2.9 & 2 & 2.9 & 3.0192 & 0.7984 \\
\hline & $\mathbf{X 3}$ & 4 & 5.9 & 11 & 16.2 & 25 & 36.7 & 20 & 29.4 & 6 & 8.8 & 3.1831 & 0.8237 \\
\hline & X4 & 14 & 20.4 & 28 & 41.6 & 20 & 29.4 & 3 & 5.8 & 1 & 1.5 & 3.0372 & 0.8830 \\
\hline & X5 & 36 & 51.8 & 13 & 18.2 & 2 & 2.9 & 10 & 14.3 & 5 & 6.9 & 3.6771 & 0.8044 \\
\hline \multicolumn{12}{|c|}{ The mean } & 3.3157 & 0.7848 \\
\hline \multirow[t]{5}{*}{ Intervention } & X6 & 4 & 5.9 & 38 & 55.9 & 10 & 14.3 & 8 & 11.8 & 6 & 8.8 & 3.444 & 0.7899 \\
\hline & $\mathbf{X} 7$ & 20 & 29.4 & 16 & 22.5 & 20 & 29.4 & 7 & 10.3 & 3 & 5.8 & 3.0882 & 0.8138 \\
\hline & X8 & 3 & 5.8 & 16 & 22.5 & 20 & 29.4 & 10 & 14.3 & 17 & 24.8 & 3.2343 & 0.9934 \\
\hline & X9 & 10 & 14.3 & 25 & 39.4 & 15 & 22.1 & 10 & 14.3 & 6 & 8.8 & 3.987 & 0.9746 \\
\hline & X10 & 2 & 2.9 & 28 & 11.8 & 20 & 29.4 & 6 & 8.8 & 10 & 14.3 & 3.499 & 0.7986 \\
\hline \multicolumn{12}{|c|}{ The mean } & 3.4505 & 0.87406 \\
\hline \multirow[t]{5}{*}{ deception } & X11 & 4 & 14.4 & 30 & 43.1 & 18 & 25.4 & 5 & 6.9 & 4 & 5.9 & 3.6064 & 0.8714 \\
\hline & X12 & 3 & 5.8 & 22 & 31.7 & 30 & 43.1 & 8 & 11.8 & 3 & 5.8 & 3.1699 & 0.8759 \\
\hline & X13 & 2 & 2.9 & 16 & 22.3 & 17 & 24.8 & 28 & 43.7 & 3 & 5.8 & 3.6695 & 0.8984 \\
\hline & X14 & 3 & 3.8 & 17 & 24.8 & 16 & 22.5 & 18 & 25.4 & 12 & 17.6 & 3.487 & 0.9185 \\
\hline & X15 & 14 & 20.4 & 18 & 25.4 & 16 & 22.5 & 18 & 25.4 & - & - & 3.9895 & 0.9075 \\
\hline \multicolumn{12}{|c|}{ The mean } & 3.4968 & 0.89434 \\
\hline \multicolumn{12}{|c|}{ Irregular Marketing } & 3.421 & 0.8510 \\
\hline
\end{tabular}

Through table (3) it is clear that:

- Weakness and change of persuasion with an arithmetic mean of (3.4968 )with a standard deviation of $89434 \%$ and a percentage of $66.310 \%$ and it ranked first.

- The intervention variable achieved an arithmetic mean of (3.4505)with a standard deviation of( 87406 )and a percentage of 64.940 , )and it came in second place.

- The deception variable achieved an arithmetic mean of( 3.315 )with a standard deviation of( 7848 )and a percentage of $\mathbf{6 3 . 9 4 0 \%}$, and it came in third place.

- The main variable achieved irregular marketing for the researched sample with an arithmetic mean of (3.421)a standard deviation of( 8510 )and a percentage of (65.063).

3.4.2 Testing the hypotheses of the correlation relationships for the main and sub-variables:-

This part is devoted to a statistical presentation, testing and analysis of relationships between research variables (irregular marketing and marketing efficiency), as follows: 
Table 4. Matrix of correlations for main and sub-variables

\begin{tabular}{|c|c|c|c|}
\hline $\mathrm{s}$ & The dimension & Marketing Efficiency & Sign. \\
\hline 1 & deception & $22 \%$ & $06 \%$ \\
\hline 2 & Intervention & $30 \%$ & $04 \%$ \\
\hline 3 & persuasion & $40 \%$ & $01 \%$ \\
\hline & Irregular Marketing & $32 \%$ & $003 \%$ \\
\hline
\end{tabular}

From the data in the table it is clear that:

The customer satisfaction variable achieved a mean of $(3,844)$, with a standard deviation of $(7717 \%)$ and a percentage weight of (76.87) and it ranked first.

- The marketing development variable achieved an arithmetic mean of( 3,724,$)$ with a standard deviation of (7090\%), and a percentage weight of( 74.63), and it ranked second.

- The marketing cost variable achieved an arithmetic mean of (3,340 )with a standard deviation of $6599 \%$ and a percentage weight of( 71.45 ,) and it ranked third.

- The dependent variable for marketing efficiency achieved an arithmetic mean of (3,636 )with a standard deviation of (7135\% )and a weight percentile of( 74.31)

Table 5. Statistical Description of Marketing Efficiency

\begin{tabular}{|c|c|c|c|c|c|}
\hline $\mathrm{s}$ & independent dimensions & mean & Standard .d & percentage & $\begin{array}{c}\text { Dimensional } \\
\text { ranking }\end{array}$ \\
\hline 1 & Customer satisfaction & 3,844 & $7717 \%$ & 76.87 & the first \\
\hline 2 & Marketing development & 3,724 & $7090 \%$ & 74.63 & The second \\
\hline 3 & marketing costs & 3,340 & $6599 \%$ & 71.45 & the third \\
\hline 4 & Total & 3,636 & $7135 \%$ & \multicolumn{2}{|c|}{74.31} \\
\hline
\end{tabular}

From the results of Table (5), testing the relationship of the effect of irregular marketing on marketing efficiency according to the results of determining the simple attraction, assuming the existence of a mechanism relationship between the real value of mystery shopping $\mathrm{x}$ and marketing efficiency $\mathrm{y}$, which is expressed by the following equation

$\mathrm{Y}=\mathrm{a}+\mathrm{BX}$

where $\mathrm{y}=$ marketing efficiency

$\mathrm{X}=$ irregular marketing

$\mathrm{B}=$ the amount of change that occurs as a result of changing its position from

$\mathrm{a}=$ statistically constant

Through this equation, it is shown that the marketing efficiency is a function of the true value of hidden marketing. The estimates of this equation and its statistical effects were calculated at the level of the research sample of 66 individuals. The simple regression equation for the relationship between the variables of irregular marketing and marketing efficiency was as follows:

Marketing efficiency $=65.06+74.31$

And through that, the ANOVH variance was analyzed for the two variables, as shown in the following table:

Table 6. ANOVH analysis of the relationship between irregular marketing and marketing efficiency

\begin{tabular}{|l|l|l|l|l|l|l|}
\hline $\begin{array}{c}\text { Contrast } \\
\text { source }\end{array}$ & Degree .free & \multicolumn{1}{|c|}{$\mathrm{R}^{2}$} & mean squares & \multicolumn{1}{|c|}{$\begin{array}{c}\text { sum of } \\
\text { squares }\end{array}$} & \multicolumn{1}{|c|}{$\mathrm{F}$} & Sign. \\
\hline regression & $\mathbf{1}$ & $\mathbf{1 1 6 \%}$ & $\mathbf{1 . 6 0 1}$ & $\mathbf{1 . 6 0 1}$ & the group & $\mathbf{0 0 4 \%}$ \\
\hline The error & $\mathbf{6 4}$ & & $\mathbf{1 8 2}$ & $\mathbf{1 2 . 1 4 9}$ & $\mathbf{8 . 6 8 6}$ & \\
\hline the total & $\mathbf{6 5}$ & & & $\mathbf{1 3 . 7 5 0}$ & & \\
\hline
\end{tabular}


Countries (7) The results of testing the relationship of the effect of irregular marketing on marketing efficiency

\begin{tabular}{|c|c|c|c|c|c|}
\hline Contrast source & \multicolumn{2}{|c|}{ Non-standard transactions } & \multicolumn{2}{|c|}{ Non-standard transactions } & \multirow{2}{*}{ Sign. } \\
\hline Sample & $\mathrm{T}$ & $\beta$ & $\begin{array}{c}\text { standard error } \\
\text { beta } \\
\text { coefficient }\end{array}$ & $\begin{array}{c}\text { standard } \\
\text { error beta } \\
\text { coefficient }\end{array}$ & \\
\hline Constant & $917 \%$ & $32 \%$ & $82 \%$ & 74 & $311 \%$ \\
\cline { 1 - 1 } Marketing is & 2.39 & & $21 \%$ & 65 & $004 \%$ \\
\hline
\end{tabular}

From Table 6 Analysis of Variance and Table 7 and the previous research sample 66 individuals, that the value of $\mathrm{T}$ was significant when compared with the new ones with a significant level of 0.05 , which indicates that the regression curve is sufficient to describe the relationship between the two variables $\mathrm{X}, \mathrm{Y}$ and with a confidence level of $95 \%$ This was confirmed by the statistical value according to the $\mathrm{T}$ test, where it reached $\mathrm{T}=2.89$ through the regression equation indicating the constant $\mathrm{a}=0.74$, and this indicates that there is a marketing efficiency of $(74 \%$ )when the value of irregular marketing is equal to zero, i.e. the marginal slope value reached (0.32)In indicates a change of 1 in irregular marketing $\mathrm{X}$ leads to a change of( $32 \%$ )in marketing efficiency.

The value of the coefficient of determination $\mathrm{R}^{2}$ amounted to( $116 \%$ )which means that irregular marketing $\mathrm{X}$ explains its value $(116 \%)$ of the variance in marketing efficiency, and that $89 \%$ of the variance determines the variables that are not included in the regression signs, and through the results presented, it was confirmed that the hypothesis was accepted.

3.4.3 Choice of sub-hypotheses:

After the main impact hypothesis has been tested, it is necessary to test the effect of irregular marketing in terms of its dimensions (deception, interference, persuasion) on marketing efficiency.

According to this hypothesis, the multiple regression equation for the irregular marketing variables $\mathrm{X} 1, \mathrm{X} 2, \mathrm{X} 3$ in marketing efficiency $Y$

Table 8. Results of testing the influence relationships between irregular marketing and marketing efficiency

\begin{tabular}{|c|c|c|c|c|c|}
\hline \multirow[t]{2}{*}{ Sample } & \multirow[t]{2}{*}{$\mathrm{T}$} & \multirow{2}{*}{$\begin{array}{c}\begin{array}{c}\text { Non-standard } \\
\text { transactions }\end{array} \\
\beta\end{array}$} & \multicolumn{2}{|c|}{ Non-standard transactions } & \multirow[t]{2}{*}{ Sign. } \\
\hline & & & $\begin{array}{c}\text { Beta coefficient B } \\
\text { standard error }\end{array}$ & $\begin{array}{c}\text { Beta coefficient } \\
\text { B standard } \\
\text { error }\end{array}$ & \\
\hline Constant & & \multirow[t]{2}{*}{0,040} & 0,832 & 0,75 & 0,372 \\
\hline deception & Constant & & 0,113 & 0,041 & 0,720 \\
\hline Intervention & deception & 0,042 & 0,117 & 0,043 & 0,710 \\
\hline persuasion & Intervention & 0,041 & 0,121 & 0,049 & 0,740 \\
\hline
\end{tabular}

From the results of Table (8), the regression equation affects the constant (0.75) which means that there is a marketing efficiency of ( 0.75$)$ when the value of irregular marketing equals (zero).

The value of the marginal slope of the deception dimension has reached 0.040 , which means that a change of 1 in the deception dimension X1 leads to a positive change of (0.040)in marketing efficiency.

The value of the marginal slope of the intervention dimension was( 0.042 , )which means that a change of 1 in the intervention dimension X2 leads to a positive change of (0.042)in marketing efficiency.

The value of the marginal slope of the dimension of persuasion has reached (0.041) which means that a change of 1 in the dimension of persuasion X3 leads to a positive change of (0.041) in marketing efficiency.

a- The first main hypothesis:-

There is a significant correlation between irregular marketing and marketing efficiency at the total level, which amounted to (0.38) and the level of morality 0.03 which is less than $(0.05)$ that the researcher determined, so the hypothesis was accepted

b- The first sub-hypothesis: 
There is a significant correlation between the dimension of deception and marketing efficiency at the total level, as it reached $(0.22)$ which is a positive relationship, and the level of morale is $(0.06)$ which is higher than the level of morale set by the researcher, (0.05)so this hypothesis was rejected at the research level.

c- The second sub-hypothesis:

There is a significant correlation between the interaction dimension and marketing efficiency at the total level. Through the table, it was found that there is a positive correlation of (0.30) and a level of (0.04)which is less than the level of morale specified by the researcher $(0.05)$ so the hypothesis was accepted at the research level.

d- The third sub-hypothesis:

There is a significant correlation between the dimension of persuasion and marketing efficiency at the total level, and through the table, it is clear that there is a positive correlation of $(0.40)$ and a morale level of 0.01 , which is less than the level of morale set by the researchers $(0.05)$ so the hypothesis was accepted at the level of search.

e. Deduction of influence relationships for the main hypothesis:

In this research, we discuss the results of testing and analyzing the impact advertisements among the research variables, according to the main impact hypothesis.

f. And based on what appeared from the results, the main hypothesis is accepted at the total level, the first hypothesis is rejected, and the second and third hypotheses of influence relationships are accepted.

\section{Conclusions and Recommendations}

\subsection{The Conclusions}

a- It was found that there is marketing information about the product for the customer, and this is what made it easy for him not to fall into the trap of marketing deception.

b. Car showrooms have a smart practice of persuading the customer in a hidden way that has achieved the customer's demand for the product, and this represents the achievement of marketing efficiency.

c. Most of the customers had contact with the marketing managers in the exhibitions to get to know the products, which

Helped to persuade relatives and friends to buy its products, thus achieving a high market share.

Car showrooms show ethical aspects in marketing their products by engaging their representatives among customers

To talk about its products and provide them with a sample of it to try and thus was able to reduce its marketing costs and achieve a high market share.

d- Car showrooms show marketing control of their products, and therefore they have taken care of after-sales services.

e. It turns out that the company has regular marketing outlets and thus achieved marketing efficiency by overcoming its competitors.

f. The research showed that irregular marketing is a contemporary strategy that achieves a better ability than traditional methods

Its focus is on the creative aspects of persuading the target customer, as well as the impressive results achieved by car showrooms that implemented this strategy.

\subsection{Recommendations}

a- The need to strengthen the ethical aspects included in irregular marketing by avoiding car showrooms from deceiving their customers, providing products that fulfill customer needs and desires, and deceiving competitors in order to reduce their marketing costs.

b- The need to enhance the customer's confidence in the products of car showrooms by moving car showrooms away from umbrella advertisements and traditional promotional methods.

c- The need to strengthen communication between marketing managers in car showrooms and customers to provide them with information about products that suit their contemporary needs and which have become different from the description of the situation in the past.

d- The need to promote modern and unfamiliar marketing methods that have a direct impact on a customer in order to purchase their products and achieve competitive advantage.

e- The need to strengthen marketing control over products and the continuous search for relevant products

High quality that meets the aspirations of customers. 
f- The need to promote the positive aspects of irregular marketing through the diversity of marketing outlets used by car showrooms to deliver products to their customers.

\section{References}

Abraham, Jay. (2000). Stealth Marketing. Abraham Publishing Group Inc.

Abu Fara. (1998). Marketing Efficiency. Jordan Omman.150-156.

Auletta, K. (2009). The End of the World as We Know It. New York. Penguin Press, HC.

Baker, M., \& Hart, S. (2008). The Marketing Book. (6th ed.).

Barry. T. E. (2002). In Defense of the Hierarchy of Effects: Rejoinder to Weilbache. Journal of Advertising Research, 24.

Berman, M. (2007). Street-Smart Advertising: How to Win the Battle of the Buzz. Plymouth, United Kingdom: Rowman \& Littlefield Publishers, Inc.

Black, N. (2009). Fly-Posting: An Exploration of a 'Controversial' Medium. Journal of Marketing Communications, 15 (4), 209-226. https://doi.org/10.1080/13527260802091022.

Bomb. (2017). Street Marketing. What is Street Marketing. Marketing-schools.org.

Borghini, S., Visconti, L. M., Anderson, L., Sherry Jr, J. F. (2010). Symbiotic postures of commercial advertising and street art: Implications for creativity. Journal of Advertising, 39(3), 115-28. https://doi.org/10.2753/joa0091-3367390308.

Boston. (2014). How to Pull Off a Guerrilla Marketing Campaign. Entrepreneur U.S.A.

Carsten, S., \& Anderson, S. (2012). Danish Mother Seeking Stealth Marketing Campaign on YouTube. Journal of Current Cultural Research, 4.

Crescenti, B. E. (2005). Under Cover Marketing: If Omission is the Mission Where is the Federal Trade Commission. Journal of Law and Policy, 13(2).

Gambetti, R. C. (2010). Ambient communication: How to engage consumers in urban touch-points. California Management Review, 52(3), 34-51.

Goldberg, L. G. (2014). Taryn Rose Launches Dresr: Street Marketing a Luxury Brand - Case - Harvard Business School. Hbs.edu.

Goldman, E. (2005). Stealth Risks of Regulating Stealth Marketing. Texas Low Review, 85(11).

Jacobs, J. (2012). Faking it - how to kill a business through a structuring on social media. Professional Updates Management, 64(9), 567-570.

Johansson. (2005). How American Marketing Excesses Fuel Anti- Americanism. UPPER Saddle River, NJ, Prentice Hall.

Kaikati, A., \& Kaikati, J. (2004). Stealth Marketing: How to Reach Consumers Surreptitiously. California Management Review, 46(4).

Kaikati, Z. (2013). Stealth Marketing Strategy: Origins, Manifestations and Practical Application. Journal of Advertising Research, 44 (4).

Martin, K. D., \& Craig, N. S. (2008). Commercializing Social Interaction: The Ethics of Stealth Marketing. Ronald Hill Prentice.

Ratfeld, H. J. (2008). The Stealth Influence of Covert Marketing. Journal of Public Policy \& Marketing, 27 (1).

Robin, G. D. (2008). Under Cover Marketing: Conversation or Commerce. Journal of Consumer Marketing, 14 (6).

Rouwmaat, V., Reid, A., \& Kurik, S. (2003). Business incubation: review of current situation and guidelines for government intervention in Estonia. Ministry of Economic Affairs and Communications of the Republic of Estonia. https://doi.org/10.13140/RG.2.2.10373.76009

Roy, A., \& Chttopadhyay. (2010). Stealth Marketing as Strategy. Journal of Business Horizons, 53.

Sakai, M. (2013). Social Problems Caused by Undercover Marketing and Social Media Traces in Japan. Academic Journal of Interdisciplinary Studies, 2.

Saucet, M., \& Cova, B. (2015). The secret lives of unconventional campaigns: Street marketing on the fringe. Journal of Marketing Communications, 21(1), 65-77. 
Scott, B. (1991). Inside the Stealth Bomber: The B-2 Story. Tab/Aero.

Simon, C., \& Nicholas, B. (2010). Ambushed!. Practical Ecommerce, Insights for Online Merchants. Webmarketingtoday.com.

Solomon, M., Marshall, G., \& Stuart, E. (2008). Marketing, Real People, Real Choices. Upper Saddle River, New Jersey, United States of America: Pearson Education.

Stairfgearg. (2005). http://dictionary.cambridge.org.

Stenberg, K., \& Pracic, S. (2005). Under Cover Marketing: The Method Which Lies Beneath. Journal of Current Cultural Research, 14 (3).

Stenberg, B., Karolina, Pracic, \& Sabina. (2005). Undercover marketing: the method which lies beneath. Fretagsekonomi.

Vector, P. R., \& Svenson, M. (2010). Stealth Marketing: The Art of Deceiving Consumers. Journal of Marketing, 57.

Vladimir, Z. M. (2015). Stealth Marketing Strategy: Origins, Manifestation and Practical applications. Journal of Consumer Research, 12 (4).

Weilbacher, W. M. (2001). Does Advertising Cause a Hierarchy of Effect. Journal of Advertising Research, 41.

Weisberg, A., Alonna, P., \& Jake, F. (2009). The Ethics of Stealth Marketing. Journal of Marketing Research, 13(2).

Zyman, S. (2002). The End of Advertising. New York .NY: John Wiley \& Sons.

Zyman, Z. (2006). The end of advertising. Journal of Marketing, 56.

\section{Copyrights}

Copyright for this article is retained by the author(s), with first publication rights granted to the journal.

This is an open-access article distributed under the terms and conditions of the Creative Commons Attribution license which permits unrestricted use, distribution, and reproduction in any medium, provided the original work is properly cited. 